\title{
Bureaucratic Abuse In The Nigerian Civil Service: A Critical Analysis
}

\author{
T. Alabi \\ Department of Sociology, \\ University of Abuja, Abuja, Nigeria
}

\begin{abstract}
As rightly observed by one of the founding fathers of Sociology, Max Weber, all modern formal organizations are bureaucratic in nature. By implication, modern complex organizations operate along bureaucratic lines. Just like other formal organization. Nigeria Federal Ministries operate bureaucracy to achieve its aims and objectives. However, there are views that tend to suggest that bureaucracy is abused by organizations by these ministries. This paper therefore takes a critical review on the extent to which bureaucratic abuses in Nigerian Federal Ministries. Existing literatures were extensively reviewed and suggestions were made based on the submissions of various scholars on bureaucratic abused in Nigeria.
\end{abstract}

Keywords: civil service, bureaucracy, civil servants, ministry and government

\section{INTRODUCTION}

The Civil Service is an administrative bureaucracy which occupies an essential position in the political system of nations. It is one of the agents of development in any nation. The transformation of any society or system depends on the effectiveness and efficiency of its civil service, particularly, the developing societies. This is because political leaders take decisions, formulate policies and programmes of national development of which the civil service system that implement them (Okafor, 2005).

In most societies of the world, the contributions of civil service in promoting sustainable and equitable economic growth are receiving increasing attention. Efficient and effective management of the civil service are critical to the sustainable socio-economic development of a nation. Ogiri (2004), stated that the East Asian experience has underscored the critical contributions of the civil service in fostering rapid development.

As observed by Peggy (2010), the civil bureaucracy or service is the term used to describes the system of authority relationships that exist between men, offices and methods that government uses to implement its programmes. This does not however cover political appointee such as ministers and Advisers or members of the judiciary at the federal, state and local government tiers of government. The primary function of civil servants therefore is to advise the political executives or appointees on all aspects of governmental activities to ensure formulation of the policy which is consonant with the objectives of the government of the day (Adeyemi and Ademulua 2009). Advice in the context of policy formulation or initiation necessary implies the collection of relevant data, together with carefully considered alternatives, which would enable policy decisions to be made by the political heads. Related to this function is to ensure that policy decisions of government are faithfully implemented. From this brief statement of the roles of the civil servants, it will be seen that the civil service is about the most significant single institution affecting the lives of the citizenry in a polity, its influence is all pervasive, more so in today Nigeria where is striving to attain good governance. 
The new Encyclopedia Britainnica (2004) defines Civil Service as the body of government officials who are employed in civil occupations that is neither political nor judicial. Bello-Iman (2005) opined that Civil Service refers to employees selected and promoted on the basis of a merit and seniority system, which may include examination. The World Book Encyclopedia (2004), noted that the Civil Service consists of people employed by the state to run the public service of a country. Abubakar (2008), argue that civil service in Nigeria comprises workers in the various ministries or departments apart from those who hold political appointments. Civil Service reform on the other hand refers to the purposeful modification of governmental human resource management system with the goal of maximizing important administrative values (Abubakar, 2008).

The civil service in Nigeria is of a colonial creation. The model of civil service bequeathed to Nigeria by her colonial master (Britain) was narrow in structure and objectives. It was basically structured in such a manner that enabled colonial masters to successfully extract the much coveted financial and material resources needed by their controlling metropolitan powers. Colonialism was therefore marked by a lack of accountability and absence of transparency. At independence in 1960 when Nigerian nationals took over the administrative leadership, no attempt was made by them to restructure the civil service to suit our own developmental needs. The Nigeria bureaucrats who occupied the leadership position in the Civil Service imbibed the colonial mentality of wealth acquisition for self -aggrandizement and self-superiority. Instead of working to improve the lot of the country, they became colonial masters in a, "black man's skin". This aggravated the abysmal performance of the Civil Service and consequently the under development of the country. These and other factors necessitated the clamour for reforms in the Nigeria Civil Service. The colonial masters carried out some reforms, among which are the Harragin Commission of 1945 which was the first commission set up to look into the Nigeria Civil Service, and the Gorsuch commission of 1954-55.

According to Adeyemi and Ademilua (2009), the Harragin Commission was the first commission set up to look into the man-power problem in the service and the discontent 0225among the European members of what was described as poor financial reward, while the Gorsuch Commission was the first to attempt giving the regional administrative bureaucracies indigenous structure. After independence, Nigerian government carried out series of reforms among which are the Adebo Commission (1971), Udoji Public Service Review Commission of 1974, Dotun Philips Civil Service Reform of 1988, Allison Ayida Committee on Civil Service of 1995. However, Nigeria is not alone in this quest for Civil Service reform. This is because according to World Bank (2012), there is a strong consensus in the international development community on the need for Civil Service reform in developing nations. It is therefore, a topical issue of the moment as developing nations all over the world engages in the struggle to better their existence through the process of reforms for efficient and effective service delivery. Significant changes have been occurring since the Mid 1970s in advanced industrialized country public administrations, governments sought to reshape rigid, hierarchical, and nineteenth-century bureaucracies into more flexible decentralized, client-responsive organization compatible with the twenty-first century technological and economic requirements. For example countries like Germany, Australia, USA, UK; and New Zealand in the 1970 s and 80's respectively embarked on what they called "New Managerialism". In countries like Ghana and Uganda incrementalism approach to their civil service reforms was adopted to accommodate their socio-cultural needs and it has been working well for them (ILO, 2007; 2012 and World Bank, 2012).

It is in the light of the foregoing that this paper critically examines the Nigerian federal civil service 


\section{FEATURES OF CIVIL SERVICE}

Nevertheless, the new civil in Nigeria has certain appreciable features or legacies, values and ideas in their conjectures such as the value of honesty, prestige, devotion, selflessness, neutrality and impartiality, that enables every bureaucratic or civil servant to work towards accomplishing public objectives (Federal Civil Service Commission (FCSC), 2010. FCSC (2010) identified some of those features like: selfless service, political neutrality, career service, professionalism.

In the same vein, NCEMA and ASCON (2000) identified other features of the civil service which includes: permanency in office, political neutrality merit system, impartiality, operation within the framework of the law, strict regulations and procedures, hierarchy and expertise.

\section{NEED FOR BUREAUCRACY IN CIVIL SERVICE}

In reality of the present modern government, public bureaucracy has become inevitable in modern society as it has become the main instrument through which any government implement social change.

First, bureaucracy aids in the framing of legislation. Bureaucrats are at their best when it comes to framing of legislation. Ogiri (2004) noted that bureaucrats play anactive role in the initiation and framing of laws which are usually recommended to the legislature for satisfaction and approval.

In the same vein Ngulde (1995; Falana, 2007) added that framing of legislation is on important function of bureaucracy that once a bill has been passed into law on a broad principle, the bureaucrats will spell out details of the legislation for effective implementation. In spelling out the details of legislation, the bureaucrat, because of this expert knowledge and information, exercises wide discretion and can extend the legislation beyond its original intents with the basic understanding that bureaucracy operates at the executive arm of the government, this function of the bureaucracy has become very important in situations of strong executives. The executives usually initiate thus most legislation, and bureaucrats train most of the executive legislation.

Bureaucrats recommend policy. according to Falana (2007.) this is perceived as a new function of the bureaucracy. Traditionally, policy is solely believed to be/ the duty of the legislations but with increasing complexities of modern government and the volume of technical legislative issues awaiting the attention of the legislatures, with the need for expertise knowledge and competence, advice and guidance, the bureaucrats are usually called up in such pressure ridden situation coupled with the urgency in technical details of some policies to assists the legislators. He further states that this role is in tandem with the understanding that technical experts of various dimensions and qualities are located in the bureaucracy, which is indispensable in the process of legislation. Samad and Amri (2011) affirmed that another importance of bureaucracy is that it enables the specialization of function. He argued that specialization converts complex activities into simple tasks with each position handling the aspect of job in which it is most competent and disposed to handle. Also that bureaucracy creates structure that the duties of each person is clearly spelt out and makes for easy coordination of organizational activities while eliminating indecision.

He went further to state that bureaucracy creates room for creditability and stability. Also, that the creditability and stability of an organization is premised on the rules and regulations, structure, specialization and other features of bureaucracy. Creditability and stability in the 
sense that it makes for order and rationalizes human relationship that would have been irrational and accidental in nature and provide certainty in the organizational activities.

Furthermore he noted rationality as an important function of bureaucracy. Fir him bureaucracy emphasizes on technical competence and qualification as the sole basis for gaining and holding a hob. In this way, there is no room for favouritism, ethnicity and nepotism; rather job opportunities and promotion are based on achievement, qualification and experience.

Meanwhile, Hambagda, (1995), Ekumankama (2002) noted other functions which includes; Engineering and implementing social change, influencing public policy, implementing public policy and discharging routine duties of government.

\section{THEORETICAL ORIENTATIONS}

There are two opposite praradigms on the study of bureaucracy. These are the Weberian and Marxian views. According to the former, bureaucracy is viewed as a large-scale, complex, hierarchical and specialized organization designed to attain rational objectives in the most efficient and effective manner. The realization of such rational goals and objectives are maximized through the bureaucratic qualities of formalism and impersonality in the application of rules and regulations in the operation and management of organizations. This classical bureaucracy of Weber is seen as a very superior organization mainly because of certain qualities such as hierarchy, division of labour anchored on specialization, policy of promotion and recruitment based on merit, in addition to impersonality in the conduct of official duties, security of tenure and strict observance of rules regulations, among others (Weber, 1964). Fiedler thesis supports Marx's view on Bureaucracy. On his own part, Karl Marx viewed bureaucracy as an instrument of oppression, exploitation and damnation in the hands of the dominant class who control and manipulate the state and its apparatus in the society. More specifically, bureaucracy is conceived as instrument usually employed by the ruling class to accumulate wealth and maintain their domination and control of the state. This basic driving force of bureaucracy is usually concealed by both the dominant class and the bureaucrats, as efforts are constantly made to project the bureaucracy as a neutral and development agency working for the interest of everybody in the society. But this is only a smokescreen to hide its real motive and responsibilities. To a very large extent, the future and interest of bureaucracy are closely interlinked with those of the ruling class and the state. According to Fiedler (1967) Jago (1988) due to the fact that bureaucracy is not an integral part of the capitalist ruling class, it has a certain measure of autonomy which makes conflict with its master possible. But in this conflict bureaucracy is always disadvantaged and the conflict itself cannot go beyond certain limits, which are always determined, by the existing social forces and relations of production. From fore going, it follows that bureaucracy does not occupy an organic place in the social structure, as it is not directly linked with the production process. Its existence and development therefore has transient and parasitic character.

A brief look at the Nigerian Civil Service no doubt reveals that bureaucracy is an apparatus of the dominant class to maintain the status quo and perpetuate inequality. For instance, the dominant class use bureaucracy to ensure that their policies and programmes are implemented in their own interest and not in the interest of the people. Again, the Nigerian Civil Service depicts a scenario where one class of people occupy administrative space thereby precluding others. The Civil Service execute decisions of the dominant class this is why the system is characterized by impartiality and neutrality so that it continues to serve the interest of the dominant ruling class (Transparency International, 2003; The TELL magazine, 2009).

Therefore, this work adopts Marxist views as the most relevant theory to this study. 


\section{BUREAUCRATIC PROBLEMS}

Despite the importance and seeming inevitability of the bureaucracy in modern society, it has been faced with a lot of problems. Even max Weber himself who is seen as the father of modern bureaucracy was fully aware of such problems and criticisms and fears about bureaucracy.

First, the division of labour which bureaucracy demands apparently leads to monotony and boredom. Most importantly it leads to alienation. This explains a situation where the workers are estrange or dissociated from the surrounding society. Being afraid of this situation, Weber wrote that "it is horrible to think that the world would one day be filled with little cogs, little man changing to little jobs and string for another bigger ones" (ILO, 2012).

Mullins (1996) argued that true division of labour has certainly enhanced the performance of many complex bureaucracies, in some cases it can lead to trained incapacity: that is workers become so specialized that they develop blind problems. Even worse, they may not care about what is happening in the next departments.

Bureaucratic values of impersonality are constantly in conflict with societal values. According to Rosenbloom and Buhari, (1998), public organization as bureaucratically organized, tends to be in tension or conflict with society in terms of style of action, emotional feelings, and overriding concerns. The differences between societal and bureaucratic values are social interaction versus doing and the beliefs randomness, and emotionalism versus specialized expertise systemization and impersonality. This is why Weber (1947) observed that in order to keep a position of mankind free from this parcelling out of the soul is mastery of the bureaucratic way of life Ogiri, (2004).

The problem of red tapes associated with the bureaucracy is one which seems highly overflogged. However, the frustrations which people meet every day in their interaction with public bureaucracies are such that still call for emphasis on this issue. Apart from the fact that many third world bureaucracies are indolent and inefficient (like Nigeria), all over the world, the adherence to rules and regulations has made the bureaucracy to be noted for its slow nature.

Alemika (2011) believe that adherence to rules is quite in order but he argues that at times it overshadows the large goals of an organization and becomes dysfunctional. If blindly applied, they will no longer serve as a means to achieving an objective instead will become important (and perhaps too important) in their own right.

The demand of conformity to official regulations has always pitched the bureaucracy against the people who find it difficult to understand why public officials cannot use their initiatives to get problems solved.

Okafor (2005) brought home this point when he wrote that: The bureaucratic culture makes certain demands upon the clients as well as upon the clients as well as upon the organization employees. There are many people in our society who have not been able to adjust to those demands. To them bureaucracy is a curse. They see no good in it whatsoever, but view the demand of modern organization on red rape.

Bureaucracy is inconsistent with democratic governance. According to Adamolekun (2006), bureaucracy is an antithesis of democracy. Although in literature, bureaucracy is efficient, but if it is compared with democracy, it is clearly seen that both principles contradicts. Democracy is a government of compromise, understanding respect of all recognition of system most of the time people are manipulated by those who they elected into position to rule, this situation has 
been described as "the illusion of democracy" democracy involves supremacy of the people, supremacy of the people in government.

This is why Abraham Lincoln defined democracy as government of the people, by the people and for the people. Unlike bureaucracy, it rules and principles of bureaucracy are stacked to and if it is not diluted it would not blend well with democratic government.

Ademola (2008) observed that it is obvious that inefficiency of civil service are discredits to the democratic government in Nigeria are all caused by the strict adherence to the bureaucratic rules by the civil service thus, leading to poor and belated policy making and subsequently Methuselah age to be implemented, all in the name of due process, while the populace which consumes the outputs are in jeopardous state. This obliviously differs from military administration, where the military administrator gives order to the civil service and it shall be carried out.

\section{CONCLUSIONS}

From the foregoing, it is clear that certain factors militate against bureaucratic practice in Nigerian civil service. Consequently, the paper concludes that indeed, bureaucracy is abused in Nigerian civil service. Again, it is concluded that the basic tenets of bureaucracy that make it the ideal type are abused in the Nigerian ministries and parasters.

Generally, this paper concludes that contrary to what obtains in the developed societies of the world, bureaucracy is not practiced in Nigerian organisations the way it ought to be. Therefore, it is not surprising that organisations in Nigeria are accused of ineffectiveness and inefficiency.

\section{References}

Abubakar, H.I. (2008) Reforms and Future of Good Governance in Nigeria. Seminar Paper presented in Department of Public Administration, ABU Zaria.

Adeyemi, T.O. \& Ademilua, S.O. (2012). Management strategy and administrative efficiency in Nigerian Universities. Journal of Strategy Trends in Education Research and Policy Studies, 3(3), 768-325.

Ademola, O. A. (2008) Impact Assessment of Corruption in the Management of Public Organisation: Case of ITEL. PGDPA Project, Department of Public Administration, ABU, Zaria.

Adamolekun, L. (2006) Politics, Bureaucracy and Development in Africa. Ibadan Spectrum Books Ltd, Ibadan.

Alemika, E.E.O. (2011) Rethinking Crime Prevention and Crime Control Approaches in Nigeria. A Key Note Address at the $11^{\text {th }}$ Annual Conference of Nigerian Sociological Society held at the University of Port Harcourt

Argyle, M. (1989), The Social Psychology of Work. $2^{\text {nd }}$ Ed. Penguin.

Bass, B.M. and Stogdili, R.M. (1990) Handbook of Leadership. Free Press.

Bello-Imam, I.B. (2005) The War Against Corruption in Nigeria: Problems and Prospects. College Press, Ibadan

Buhari, M. (1998) "Leadership and Accountablity in a Period of Moral Crisis" (in Mahadi, A. and Kwanashie, G. Leadership, Accountability and the Future of Nigheria, 1999, Arewa House, ABU, Kaduna Annual Lecture Series.

Ekumankama, D.U. (2002), Law, Corruption and Other Economic Crimes in Nigeria Today: Problems and Solution. New World Publishers, Jos.

Falana, F. (2007) “Governance, Rule of Law and Anti-Corruption” in The Punch December 10.

Federal Civil Service Commission (2012) Employment Enrolment Report.

Federal Government of Nigeria (2010), Statistics New, Abuja: Publication of the Federal office of Statistics.

Fiedler, F.E. (1967), A Theory of Leadership Effectiveness. McGraw-Hill.

Hambagda, O.A. (1995) The Civil Service, Accountability and Good Governance, Paper presented at National Conferences on Good Governance and Accountability in Nigeria, University of Maiduguri 
International Labor Organization (2005). Youth: Pathway to Decent Work - (defining youth). Geneva: International Labor Office.

International Labor Organization. (2007). Global Employment Trends. Geneva: International Labor Office.

ILO (2007), Entreprise-ba5sed Youth Emlopment Policies, Strategies and Programmes: Inititative for the development of enterprise and strategies, ILO Skills working paper No. 1

International Labour Organization (ILO) (2008). Facts on Women at Work.www.ilo.org/public/english/region/eupro/budapest/download/womenwork.pdf Accessed: 5th March 2009.

International Labour Organization (ILO) (2007). Global Trends for

WomenBrief.www.ilo.org/public/english/region/ampro/cinterfor/temas/gender/news/getw07.pdf Accessed: 5th March 2009

ILO (2011), Entreprise-based Youth Emlopment Policies, Strategies and Programmes: Inititative for the development of enterprise and strategies, ILO Skills working paper No. 1

ILO (2012), Global Employment Trends 2012: Preventing a deeper jobs crisis

Jago, A.G. (1988), The New Leadership Managing Participation in Organisations. Prentice-Hall.

Mullins, L.J. (1996) Management and Organisation Behaviour. Pitman Publishing, London

National Bureau of Statistics (NBS), 2012, National Employment Summary- Unpublished

NCEMA and ASCON (2000); "Capacity Building and Assessment Survey in the Nigerian Public Sector" Technical Report Presented at the Capacity Building Workshop organized by the Federal Ministry of Finance, Sheraton Hotels and Towers, Abuja, February.

Nigerian Institute of Social and Economic Research (NISER) (2005). Unemployment in Nigeria: Situational analysis. Monograph. Ibadan: Nigerian Institute for Social and Economic Research.

Ngulde, M.A. (1995) The Audit Department and Accountability in the Civil Service Paper presented at NationalConferences on Good Governance and Accountability in Nigeria, University of Maiduguri

Ogiri, P. (2004) Judiciary Perspective of Public Administration and Good Governance. Paper presented at Judicial Council Conference, Abuja.

Okafor, E.E. (2005). Executive Corruption in Nigeria: A Critical Overview of Its Socio-Economic Implications for Development. African Journal for Psychological Study of Social Issues, 8(1), 21-41.

Peggy, S. (2010) Stress and Health: Major Findings and Implications. Journal of Health and Social Behaviour vol 3. No2. Pg41-53

Samad, S. \& Amri, S. (2011). Examining the influence of organisational politics on job practice. Australia Journal of Basic and Applied Science, 5(12), 1353-1363.

TELL Magazine (2009), “Rich Men, Poor Nation: Politicians' Pay Drains the Economy”, No. 34, August 24.

Transparency International Report (2003) "Corruption Perception Index".

The Punch (2007) “Police, PHCN, Customs Top Corruption List”, June 14.

Weber, M. (1948) Theories of Economics and Social Organisations. Free press, New Yoke, USA

World Bank (2012) Publication Putting Nigeria to Work 